\title{
MITAKUYE OYASIN AS A FOUNDATION FOR THE WELL-BEING OF ANIMAL LIFE: REASON, NATURE, AND OPPRESSION IN HORKHEIMER, MACINTYRE, AND MIDGLEY.
}

\author{
Mitakuye Oyasin como um fundamento para o bem-estar da vida animal: \\ Razão, natureza e opressão em Horkheimer, Maclntyre e Midgley
}

Jeffery L. Nicholas

Providence College (USA)

\begin{abstract}
Resumo: Neste artigo lanço três tradições umas contra as outras para levantar algumas questões de pesquisa futura sobre a natureza da razão e a razão da natureza. Max Horkheimer e Theodor Adorno, da Escola de Frankfurt, sustentavam que a razão tende a dominar a natureza e que a dominação é parte da essência da razão. Dirijo-me, então, para examinar Aristóteles e aristotélicos contemporâneos, mais precisamente Mary Midgley e Alasdair Maclntyre, para mostar um recurso possível na tradição da filosofia ocidental na qual a razão emerge da natureza. Usando modernos estudos de animais, Midgley e MacIntyre ampliam a visão aristotélica sobre a natureza da razão como parte de nossa natureza animal. Por fim, discuto os Lakotas, Primeina Nação dos povos da América do Norte, que tem uma visão da razão que é o espelho oposto daquela encontrada na modernidade. Essa comparação sugere que dominar a natureza não é essencial à razão.
\end{abstract}

Palavras-chave: Razão, Natureza, Opressão, Horkheimer, Maclntyre, Midgley

\begin{abstract}
I play three traditions against each other in this paper to raise some questions for future research about the nature of reason and the reason of nature. Max Horkheimer and Theodor Adorno of the Frankfurt School contend that reason tends to dominate nature and that domination is part of the essence of reason. I then turn to examine Aristotle and contemporary Aristotelians, namely Mary Midgley and Alasdair MacIntyre, to show a possible resource within the tradition of western philosophy in which reason arises out of nature. Using modern animal studies, Midgley and MacIntyre extend the Aristotelian insight into the nature of reason as part of our animal nature. Finally, I discuss the Lakota, a First Nation people of North America, who have a view of reason which is the mirror opposite of that found in modernity. This comparison suggests that dominating nature is not essential to reason.
\end{abstract}

Keywords: Reason, Nature, Oppression, Horkheimer, Maclntyre, Midgley. 
Mitakuye Oyasin (“We are all related"). - Lakota saying

"Therefore, since everything is a possible object of thought, mind in order, as Anaxagoras says, to dominate, that is, to know, must be pure from all admixture."

- Aristotle, De Anima Book 3

The possibility of a self-critique of reason presupposes, first, that the antagonism of reason and nature is in an acute and catastrophic phase, and, second, that at this stage of complete alienation the idea of truth is still accessible. - Max Horkheimer, Eclipse of Reason (1947)

The story of reason is multifaceted and complicated and needs to be understood if humanity - if homo sapiens living in a human society - are ever to escape from oppression and achieve well-being. Alasdair Maclntyre has told part of this story in his work on tradition and practices, and I continued that story in Reason, Tradition, and the Good where I extended Maclntyre's analysis of tradition of enquiries into cultural traditions, like that of the Lakota. Yet, the story of reason goes beyond tradition, as I argued there, to that of nature, especially the nature of this beast called "man." Horkheimer's claim about the self-critique of reason suggests that, only when we come to reason with an understanding of human beings as related to nature will we be able to begin to overcome oppression. While the human relationship to nature is a centerpiece of much thinking of First Nation Peoples like the Lakota, Aristotle stands out in Western philosophy as one who saw the unity of human beings with nature. Contemporary Aristotelians Alasdair Maclntyre and Mary Midgley reclaim that Aristotelian insight, arguing that human reason arises out of non-human animal reasoning. In this article, I will present Horkheimer's claims on the disease of reason to set up the problem. I will then examine Aristotle's discussion of reason in relation to non-human animal life and expand on that Aristotelian view through Maclntyre and Midgley. Finally, I will argue, using the Lakota as an example, that the "western" conception of reason is exactly a cultural expression of reason arising from a particular relationship with nature. Using insights from Aristotle and the Lakota could point us in 
the direction of a new conception of reason, one less hostile to nature. Given the multiple positions discussed in this article, I can only point to a future project that seeks to unify reason and nature. That work itself must come later.

\section{Horkheimer on the Disease of Reason}

Axel Honneth (2009) contends that critical theory can be seen as a diagnosis of and response to the pathologies of reason. The Dialectic of Enlightenment is Horkheimer and Theodor Adorno's critique of modern reason. Modern and Enlightenment philosophers conceived the task of philosophy to free human beings from oppression of nature and society. Modern philosophers viewed reason as opposed to tradition, superstition, and faith; it is a corrective that individuals needed to escape fear. In the light of fascism and capitalism, Horkheimer and Adorno ask, "how did reason come to fail to bring about enlightenment? Why is it that everywhere people still live in chains?"

Horkheimer and Adorno situate the Marxist critique of capitalism into a larger discussion of domination. They contend that capitalism is only one form of domination, domination of homo sapiens and of nature. This domination results, in part, from a particular form of reason-subjective rationality. Subjective rationality names both an instrumental rationality and a formal rationality. Instrumental rationality is a rationality that does not question ends but seeks the most efficient means to the end. Formal rationality is both logic and categorization; no ends are given.

Though I have examined this account of subjective rationality elsewhere (2012), one aspect demands more discussion-the relationship between reason and the domination of nature. Horkheimer and Adorno link the domination of human beings to the domination of nature. "The 'happy match' between human understanding and the nature of things that [Bacon] envisaged is a patriarchal one: the mind, conquering superstition, is to rule over disenchanted nature. Knowledge, which 
is power, knows no limits, either in its enslavement of creation or in its deference to worldly masters" (DOE 2). Philosophers and scientists latched onto subjective rationality as a means to control nature through the mind. In the process, subjective rationality also dominates the mind.

The nature of this domination is not sui generis to the modern world. Horkheimer and Adorno argue that philosophers attempted to disenchant the world through reason. The ancient Greek metaphysicians rid themselves of mystical and mythical forces by considering the power of things. The Platonic and Aristotelian systems "assimilated" the powers of the gods. These systems, though, were rejected by modern philosophers who "feared the demons" that existed in the powers of Platonic and Aristotelian substances. Hidden and immanent powers were rejected for matter that was calculable-quantifiable and useful. In doing so, however, Enlightenment philosophers undermined their own project. "In the process, [rationality] treats its own ideas of human rights exactly as it does the older universals. Every spiritual resistance it encounters serves merely to increase its strength" (DOE 6). Homo sapiens, as part of nature, become something to control, and the appeal to universal rights is treated as just so much superstition.

Horkheimer takes up this theme again in The Eclipse of Reason (1974). According to Horkheimer, "the disease of reason" is that it was "born from man's urge to dominate nature" (176). This urge for domination is part of reason "from its very beginnings." It makes of nature a "mere object" and then cannot find itself objectified in nature. Reason cannot find itself in matter and things nor in gods and spirits. Thus, an antagonism appears between reason and nature, between homo sapiens and nature. To cure the disease of reason, Horkheimer insists that we need some insight into the nature of the original disease. This insight involves seeing reason as "concretely realizing its naturalness - which consists in its trend to domination - the very trend that paradoxically alienates it from nature" (177). 
Insightfully, then, Horkheimer and Adorno link the domination of homo sapiens to the domination of nature through the working of reason. Specifically, homo sapiens objectifies nature in an attempt to manipulate it. For Horkheimer and Adorno, reason becomes, like myth, mere manipulation: as the shaman tried to control disease, the modern authority figure-capitalist, statesman, scientists-tries to control humanity. Reason leads to manipulation because, according to Horkheimer, homo sapiens has an urge to dominate.

We can pause, however, to question this understanding of homo sapiens. On the one hand, Horkheimer and Adorno are right to point to Bacon as prescribing the modern ethos-the elimination of fear through the domination of nature, a domination that must entail the domination of human being as homo sapiens. The only way free from this domination is to separate off the freedom of homo sapiens from the physical reality of the human being. Yet, to continue with Horkheimer and claim that reason by nature tends to domination seems to go further than necessary. First, the historicity of reason demands that we put to question the appearance of reason in the western world. Is the dominant form today-that of subjective rationality-the only form of reason either in "western" civilization or in the world? Horkheimer cannot believe so, because he contrasts subjective rationality with objective reason. Yet, he could push back here against the question, for, according to Horkheimer, objective reason itself turned to manipulation. Yet, what of other cultures with other forms of reason? This question will drive me, in the end, to ask after the Lakota.

Both the DOE and Eclipse examine a particular historico-cultural instantiation of reason. Following Maclntyre, I have argued that reason is constituted by and constitutive of concrete traditions and practices. If so, then we must pause to consider what concrete form of reason Horkheimer's and Adorno's criticism target. Moreover, we must contextualize concretely the appearance of reason within any concrete tradition. The co-constitutive nature of reason and tradition entail that the role of domination will affect both the tradition and reason. Thus, we must question 

were horrific periods for homo sapiens, and Horkheimer and Adorno wrote as exiles from their native Germany during the Holocaust period. We cannot blame them, nor cultural artists-like Stanley Kubrick 20 years later-and thinkers-like Lawrence Konrad, for focusing on the aggressiveness of homo sapiens at that time period. Yet, we must be careful to parse out the relationship between aggression and domination and between the appearance of any urge to domination in any culture.

I am not arguing, of course, that non-European cultures had no urges to domination. The myth of the noble savage is just as much a form of domination as any racial stereotype. Rather, we must examine concrete traditions, concrete forms of reason, to determine how domination might be instantiated and justified in any concrete lived experience. Within the "western" canon we can discover some lines of thought that avoided legitimizing domination and forms of reason that sit uneasily with the idea of reason as tending necessarily to domination. I wish to examine Aristotle's concept of reason and its reassessment by modern day Aristotelians as one such form of reason.

\section{Aristotle on Reason}

Aristotle comprises both a towering and contentious figure for contemporary critical theorists. On the one hand, Aristotle lays out a clear and inspiring notion of well-being in his concept of eudaimonia as flourishing or functioning well. He claims, in the Politics, that the best city is one in which each citizen, rather than a few, flourishes. Further, he brings philosophy to the concrete level of every day practice. Aristotle's concept of praxis lies at the foundation of critical theory from Hegel's Aristotelianism that is transformed into Marxist practice. On the other hand, Aristotle denigrated women and defended natural slavery and developed a political system constructed to allow the few elites to achieve eudaimonia at the expense of the masses. I suggest that, when it comes to the disease of reason, Aristotle must be reclaimed for critical 
theory in a way that preserves the essence of his thought while removing the dross. In particular, Aristotle brings us as close as possible to an understanding of homo sapiens that mirrors that of non-Western philosophies like that of the Lakota. Specifically, in Aristotle we can discover the resources to develop a philosophy of mitakaye oyasin in which human beings are seen as one with nature.

When turning to Aristotle as a resource, critical theorists must turn to his philosophical anthropology (what MacIntyre calls his metaphysical biology). Can we discover in Aristotle's biology a ground that undermines the antagonism of reason and nature while preventing the acceptance of a biology that justified natural slavery and the subjugation of women? I believe, in fact, that we can. Aristotle, unlike many other philosophers, "stands as the biologist among philosophers-indeed as the inventor of the biological attitude, which takes the world as a continuous organic whole to be studied and accepted on its own terms, not as a tiresome mass of matter tolerable only because it instantiates mathematical laws" (Midgley 1995, 250n). Both Mary Midgley and Alasdair MacIntyre have in fact recovered Aristotle in this way. Before turning to their approaches, however, I want to highlight the important elements of Aristotle's anthropology for this recovery.

First and foremost is Aristotle's grounding of anthropology in his biology. In particular, the notion of soul provides a foundation for understanding the relationship between human beings and nature. This biology begins with Aristotle's metaphysics, his hylo-morphism.

For Aristotle, if we want to understand the world we must begin with substance. A substance is this or that concrete individual existent-this gold atom, that cat, Socrates. All substances are composed of two principles-form and matter-which cannot exist without the other. Unlike other philosophers, for example Plato, who posited that form (the immaterial) and matter exist independently, Aristotle claimed that form and matter only exist as principles in substance. Form determines the kind of 
thing a particular substance is, and matter individuates the form. This gold atom is individuated gold-ness, or individualizing matter actualized as gold.

For Aristotle, living substances are sufficiently distinct from non-living substances that they have special forms. Aristotle calls these forms souls. The soul names the form, or first act, of a body with the potential for life (De Anima II. 1) -that is, of this or that living substance. It is "in some sense the principle of animal life" (De Anima I. 1). Socrates, the cat, and the tree all have souls because they are each living bodies. Because the soul is a form of this or that living body, it cannot exist separated from matter. Further, all living beings have souls-not just homo sapiens or men, but the red maple outside my window, Coco the cat on my lap, and the ant trying to get into my honey jar all have their individual souls. Life is defined as exhibiting certain characteristic activities and these activities define the different types of souls. All living beings take in nutrition and reproduce, which comprise the two activities of the vegetative soul. Some living beings have the power of sensation and of movement, as well as nutrition and reproduction, and thus have a sensate soul. Finally, some beings-for Aristotle, homo sapiens - have the power of reason, as well as nutrition, reproduction, sensation, and movement. Homo sapiens have rational souls, then.

These levels of soul do not necessitate that some homo sapiens have less reason than others. It does not entail, for instance, that some people should be slaves according to their natural features. Nor does it entail that women should be kept from politics or are less reasonable than men. While Aristotle's defense of slavery rests on a mistaken sociology of human beings and his misogynous conclusions rests on a mistaken understanding of generation, the hylo-morphic theory of souls does not rest or depend, in any way, on this mistaken sociology or theory of generation.

His hylo-morphic theory of souls, however, entails both a certain equality with nature and, more importantly, a naturalistic understanding of reason. I am not suggesting that Aristotle believed in a principle like the Lakota Mitakaye Oyasin or that Aristotle should be forgiven for his views on slavery and women. Rather, I am 
suggesting that, in the western philosophical tradition stemming from the ancient Greeks, the Aristotelian tradition provides resources for rethinking the "disease of reason" and that those resources are primarily his anthropology, despite the negative elements that are not essential to the theory, and his understanding of reason.

Aristotle's comments on the polis and on reason at the beginning of the Politics points to the relationship between human beings and other non-human animals and to reason as a natural phenomenon.

\begin{abstract}
Now, that man is more of a political animal than bees or any other gregarious animals is evident. Nature, as we often say, makes nothing in vain, and man is the only animal whom she has endowed with the gift of speech. And whereas mere voice is but an indication of pleasure or pain, and is therefore found in other animals (for their nature attains to the perception of pleasure and pain and the intimation of them to one another, and no further), the power of speech is intended to set forth the expedient and inexpedient, and therefore likewise the just and the unjust. And it is a characteristic of man that he alone has any sense of good and evil, of just and unjust, and the like, and the association of living beings who have this sense makes a family and a state (Politics 1.2: 1253a14-18).
\end{abstract}

First, Aristotle distinguishes homo sapiens, not from, but among other animals. That is, in his comments about bees and other gregarious animals, Aristotle is situating human beings within the animal kingdom, not as something separate and distinct from the animal kingdom. Second, human speech is related to voice which all animals share. Yet, it proves distinct because it allows homo sapiens to determine what is expedient and what not and what is just and unjust. The ability to discuss the just and the unjust makes homo sapiens a political animal-one suited to living with others as family or state.

The importance of Aristotle does not end with this understanding of the relationship between human beings and non-human animals. His comments on speech also prove relevant. The Greek word for speech-logos-is also the word for reason. Thus, what Aristotle says here about speech proves relevant in relation to Horkheimer's concerns. When Aristotle notes that speech allows homo sapiens to 
determine the expedient and inexpedient, then he certainly falls under the umbrella of Horkheimer and Adorno's critique of subjective rationality. That is, logos focused on the expedient and inexpedient is similar to subjective rationality with its focus on instrumentality. Yet, human logos allows for more than determining the expedient and the inexpedient; it also allows human beings to determine the just and unjust. In short, logos aims, not only at the expedient, but also the just-the evaluation of human ends for flourishing. Aristotle points to a dialectical aspect of reason, then. As determining the expedient and inexpedient, logos may subvert human ends and lead to domination. As determining the just and unjust, logos functions to undermine any push toward domination and to establish justice.

Aristotle develops this line of thought both in the De Anima (434a5-12) and the Nichomachean Ethics (1112a 19 -1113a 14). In the De Anima, Aristotle claims that non-human animals have the power of sensory imagination - that is, a sensory object. Yet, homo sapiens have deliberative imagination which grounds the syllogism in decision-making. In the Nichomachean Ethics, Aristotle explains deliberation more carefully. Deliberation is necessary for decision that, in turn, grounds voluntary action and virtue. Decision names the actual decision an agent makes. Deliberation, however, names the process by which one weighs the various means to some end. Deliberation, then, necessarily entails determining the just and the unjust.

Horkheimer and Adorno condemn subjective rationality because it removes the ability of human beings to evaluate their ends. Rationality tends to domination because it tends to control. Aristotle's discussion of deliberation, however, shows that human beings have the ability to weigh ends. Deliberation serves as a counter-weight to the urge to domination. Speech and deliberative reason allow individual homo sapiens to seek the good - the just and unjust, and it arises out of our animal nature. Thus, Aristotle provides a useful focal point to consider the disease of reason both because of how he places human beings in the animal kingdom and how he conceives of reason. Both of these aspects of Aristotle's philosophy allow contemporary 
Aristotelians to develop a philosophical anthropology that can be seen as a philosophy of Mitakaye Oyasin-that is, brother- and sisterhood in nature. This philosophical anthropology can provide a corrective to the disease of reason that is subjective rationality.

\section{Contemporary Aristotelians on Reason: Midgley and Maclntyre}

Neither Midgley nor Maclntyre uncritically appropriate Aristotle. Commenting on Aristotle's notion of reason, Midgley criticizes him for emphasizing reason because of its peculiarity to "man" rather than its value. "And it is surely possible a priori that the point on which humanity is excellent is one in which is it not wholly unique..." (Midgley 1995, 43). She, further, associates Aristotle with other philosophers, like Nietzsche, Plato, and Kant, who discuss animals only to contrast their wickedness to human goodness. Such antagonism cannot be maintained, in fact, for, just as human life is not all angelic, animal life is not all beastly. She further takes Aristotle to task for distorting human motivation to such an extent as to make it meaningless (Midgley 1995, 119). For his part, Maclntyre rejects Aristotle's project of a metaphysical biology $(1982,162)$ resorting to sociology as a ground for his critical project. As Christopher Lutz explains, Aristotle's biology must be rejected for several reasons: it is demonstrably false regarding sexual reproduction as shown by modern biology, species are not eternal, and it no longer explains the world as we discover it (Lutz 2004, 130-1).

Given their rejections of aspects of Aristotle's biology, what about their different accounts of human nature are Aristotelian and how are those aspects relevant to the goal of understanding and undermining the disease of reason? As I have suggested throughout, the most relevant aspect of Aristotle's philosophy is the way that Aristotle situates human beings in the natural world. As Midgley states, he is the biologist among philosophers. Both Midgley and Maclntyre attempt to emulate Aristotle in understanding "morality as an expression of natural human needs" 
(Midgley 1995, 250n; see also, Maclntyre 1999, x). Central to any Aristotelian account of human nature is an account of practical reasoning. If we begin with Midgley and Maclntyre and situate human beings within nature, then reason too must be an aspect of nature, an aspect whose essence is more than an "urge to dominate."

Midgley, like Aristotle, understands that reason is deliberation. This deliberation originates in our natural demands. These demands are not overpowering, insatiable, and unlimited. Understanding such demands as overpowering, insatiable, and unlimited leads to a picture of reason that Horkheimer rejects. That is, conceiving of natural demands as overpowering, insatiable, and unlimited entails that "Reason" is an "arbitrary ringmaster or alien colonial governor, striding in to cow them all into submission" (Midgley 1995, 75). Reason as arbitrary ringmaster identifies the kind of reason as domination that Horkheimer and Adorno take aim at. Midgley contrasts this dominating reason with an understanding of reason as completing a balance between our natural demands (Midgley 2010, 64). Sadism, for instance, has its place in homo sapien life, but reason fails when sadism becomes the over-riding or a policy of life (Ibid, 76).

Reason, then, "include[s] a definite structure of preferences, a priority system based on feeling. Now that kind of structure is not peculiar to the human race, but also found in the higher animals" (Midgley 1995, 246). Reason, for Midgley, comprises, not simply a former process opposing feeling found only in homo sapiens, but a thick fluid ability to balance and interact with feelings shared with non-human animals. Reason grows out of and completes "a natural balance of parts" and belongs to a continuity of homo sapien abilities (Midgley 1994, 250). Reason works with feeling-with the whole structure of our desires and natural drives - to allow individual homo sapiens to find balance in their lives and achieve life, and not simply life but flourishing life. Reason is part of nature, but accepting this fact does not mean that one reduces reason to nonrational elements the way Nietzsche and Foucault, on one hand, and Richard Dawkins and E. O. Wilson, on the other hand, do. 
Maclntyre develops this same line of thought in his own fashion. In Dependent

Rational Animals, Maclntyre explains human life as both vulnerable and independent from which a variety of dependent and independent virtues arise. As with Aristotle, Maclntyre sees practical reason as necessary for independent moral agency; yet, unlike Aristotle, he does not strictly differentiate human logos from the non-human animal world. Discussing the nature of language in relation to a variety of philosophers including Heidegger and Davidson, Maclntyre shows the richness of the non-human animal world and, thereby, argues that some non-human animals are pre-linguistic. For Maclntyre, pre-linguistic animals are not the same as non-linguistic animals. Prelinguistic animals, like dolphins and chimpanzees, have beliefs and reasons for acting.

Following Thomas Aquinas, Maclntyre insists that animals have "a semblance of reason" and a "natural prudence" (1999, 55; cnf. ST I-II Q. 3, Art. 6). Animals, for instance, can be corrected by a trainer's direction, which requires recognizing the trainer's intention (16); dolphins perceive things and can identify objects and have a sophisticated form of communication (27); dogs change their beliefs as evidenced by the fact that, when chasing a cat, they chase the cat in different places (32); cats can distinguish between shrews (which taste horrible) and mice (37). These examples show, not that animals lack beliefs and reasons, but that animals have indeterminate beliefs and reasons just as homo sapiens do. Maclntyre concludes "adult human activity and belief are best understood as developing out of, and as still in part dependent upon, modes of belief and activity that we share with some other species of intelligent animal" (41).

Maclntyre continues his argument by turning specifically to practical reason. Non-human animals have pre-linguistic reasons for their actions. The cat cannot linguistically explain the difference between a shrew and a mouse nor name them, but the cat has a reason for chasing the mouse and avoiding the shrew. Likewise, homo sapiens have pre-linguistic reasons for action "prior to any reflection" $(1999,56)$. Human infants and children lack reflective reasoning and a linguistic ability to 
articulate their reasons, yet they still act from reason. Denying that we have such prelinguistic reasons, further, "would render the transition to specifically human rationality unintelligible." Thus, Maclntyre insists that we conceive of human beings as existing along a spectrum shared by all animals from non-linguistic to pre-linguistic to linguistic animals (which grouping might include dolphins as well as homo sapiens and homo neanderthalensis).

Maclntyre and Midgley in Aristotelian fashion, then, argue, not only for continuity between human beings and non-human animals, but for the naturalness of reason. Human reason makes no sense separated from the animal world. "'Man as a purely rational being, divested of his animal heritage of instincts, would certainly not be an angel-quite the opposite'" (Midgley 1994, 271, quoting Butler). Rather, reason arises as a capacity of animal life that acts in continuity with everything that is homo sapiens. Human beings are related to all living things. Reason understood as a capacity for deliberation allows us to question domination where it appears. Yet, the story that Horkheimer and Adorno weave suggests that something about reason essentially tends toward the domination of nature. I turn to the tradition of the Lakota and their notion of Mitakaye Oyasin to merely point-and that is all I can do for now-to an alternative understanding of the relationship between human beings and nature.

\section{Mitakaye Oyasin and the Disease of Reason}

Midgley and Maclntyre demonstrate the continuity of human beings with nature and of the human faculty of reason with similar faculties among non-human animals. They do so from an Aristotelian basis, and they do so in a way that mirrors a belief among many First Nation Peoples, including the Lakota.

The Lakota, who occupy the Dakota territories and upon whom so much popular culture has focused, believe that "we all are related." Thomas Hoffman (1997) and Marilyn Holly (1994) have investigated differences between the philosophies of First Nation Peoples and "western" philosophy stemming from the ancient Greeks. 
Where much of European-American philosophy embraces hierarchy and difference, many (but not all) First Nation Peoples embrace equality and similarity. I have shown that, despite Aristotle being the biologist among philosophers, he still embraced a hierarchical ordering of the world. His biology, in fact, led him to suppose a natural hierarchy, not only of men over animals, but of some men over others and of men over women. Such hierarchies do not appear among the Lakota.

Holly represents the difference between European and First Nation People traditions in the metaphors of the power pyramid and the Sacred Hoop. The Lakota believe that wakan inhabits the living, though wakan is not an individual immaterial entity like a spirit or dualistic soul. Rather, wakan names something "sacred, not entirely predicable to humans, and mysterious. . . Each creature or entity is conceived of and experienced as a Thou, in the terminology of Martin Buber" (Holly 1994, 16). Experienced as "thou," each creature is related to-a brother or sister-each other and equal because of that relationship. For the Lakota, human beings belong to nature and are not separate from it. Importantly, this "animistic" philosophy does not deny transcendence, but, importantly, includes non-human animals in the transcendent world.

In contrast, European culture imagines the world as a power pyramid. For many, God (or gods) sit at the pinnacle of this pyramid, followed closely by immaterial beings (like angels), man, and then the rest of created nature. The Abrahamic religions, further, imbue homo sapiens with spirit and deny spirit to other living beings. Rene Descartes solidifies this division between man and nature by separating mind from body as two separate and incommensurable substances. Contemporary cognitive science and $\mathrm{Al}$ research hinges on the distinction between mind and body first, in reducing mind to matter in empirical and theoretical research and, second, in seeking to create a disembodied mind in a computer driven "brain." In their materialist program, however, cognitive scientists, Al engineers, and modern philosophers fail to escape the power pyramid that underwrites Horkheimer and Adorno's diagnosis of the 
disease of reason. Mind is determined to manipulate, and thus control, itself through creating itself within a synthetic being. The creation of artificial intelligence will demonstrate that Descartes' dismissal of animals as automatons only proves true of human beings as well. Thus, as Horkheimer and Adorno show, reason undermines itself through its own unreason.

In this light, the Lakota mantra "Mitakaye Oyasin" proves important for it shows the tradition-constituted nature of reason. In particular, it shows that reason itself is constituted by tradition, and that the tradition of western philosophy and monotheistic religion emphasizes the role of reason in the dominion of nature. It highlights, in fact, that the disease of reason is a disease of reason as found within western modernity as that historical period stems from the ancient Greeks via Christian Europe. On the other hand, the discussion of Aristotle and of contemporary Aristotelians, Midgley and Maclntyre, show that this reading of reason is only one possible reading. In fact, much in Aristotle supports a different reading in which human beings exist along a spectrum of all created nature in which "dominion" has little role for human well-being.

I am arguing, then, that Mitakaye Oyasin understood as an Aristotelian can understand it, provides a foundation for understanding reason in a much different way than that understood by Horkheimer and Adorno and as understood by much European-originated philosophy. As suggested in my discussion of Midgley and Maclntyre, this Lakota-influenced understanding of reason highlights reason's continuity with the other faculties of homo sapiens, the continuity of human reasoning with that of non-human animals, and the role of reason in achieving balance among our human drives.

More importantly, though, this account of reason as an aspect of nature shows that reason does not have an innate urge to dominate. Nor is reason reducible to Humean instrumentalism. The cure for the disease of reason lies in a richer conception of reason as a faculty of homo sapien nature. Reason simpliciter and nature 
simpliciter are not antagonistic. Reason as conceived by the Greeks and developed within European philosophical traditions is opposed to nature as conceived by the Greeks and developed within the European philosophical traditions. Those traditions cannot be separated from the Abrahamic religious traditions that influenced their development. This conclusion entails, then, that we approach reason in a much different way than we have heretofore approached it. It entails, further, that the wellbeing of animal life, including the life of homo sapiens, requires as a necessary condition a more naturalistic understanding of reason. Reason is a faculty of homo sapiens evolved in the context of species that were navigating a world rich both in perceptual data and in social relationships. Thus, we return to Aristotle, that homo sapiens are by nature political animals because speech-logos-allows one to determine the just and the unjust. This determination of the just and the unjust, though, demands that we must recognize the continuity of reason in nature so that, rather than the oppression of a distorted subjective rationality, we might develop the well-being of animal life, both for non-human and human animals.

\section{References}

ARISTOTLE. De Anima translated by J.A. Smith. Ebook version http://ebooks.adelaide.edu.au/a/aristotle/a8so/, accessed 12 July, 2012.

. Nichomachean Ethics translated by W. D. Ross. Ebook version. http://ebooks.adelaide.edu.au/a/aristotle/nicomachean/, accessed 12 July, 2012.

Politics trans. Benjamin Jowett. Ebook version http://ebooks.adelaide.edu.au/a/aristotle/a8po/index.html, accessed 12 July, 2012.

HOFFMAN, Thomas J. "Moving beyond Dualism: A Dialogue with Western European and American Indian Views of Spirituality, Nature and Science." Social Science Journal 34, no. 4 (October 1997): 447-61.

HOLLY, Marilyn. "The Persons of Nature versus the Power Pyramid: Locke, Land, and American Indians." International Studies in Philosophy 26, no. 1 (1994): 13-31.

HONNETH, Axel. Pathologies of Reason: On the Legacy of Critical Theory trans. James Ingram, NY: Columbia University Press, 2009. 
HORKHEIMER, Max. Eclipse of Reason. New York: Continuum, 1973.

HORKHEIMER, Max and Theodor Adorno. The Dialectic of Enlightenment. New York: Continuum, 1994.

LUTZ, Christopher Stephen. Tradition in the Ethics of Alasdair Maclntyre: Relativism, Thomism, and Philosophy New York: Lexington Books, 2004.

MacINTYRE, Alasdair. After Virtue. Notre Dame, IN.: UNDP, 1982.

Dependent Rational Animals: Why Human Beings need the Virtues Paul Carus Lectures 20. Chicago: Open Court, 1999.

MIDGLEY, Mary. Beast and Man: The Roots of Human Nature London: Routledge, 1995. . The Solitary Self. Durham: Acumen Publishing, 2010.

NICHOLAS, Jeffery L. Reason, Tradition, and the Good: Maclntyre's TraditionConstituted Reason and Frankfurt School Critical Theory Notre Dame, IN: UNDP, 2012. 